\title{
Analysis of Botulinum Neurotoxin Detection by Mass Spectrometry in Forensic Samples
}

\section{Harvey J M Hou*}

Department of Physical Sciences, Alabama State University, USA

\begin{abstract}
Microbial forensics is emerged as a new interdisciplinary field and focuses on the characterization, analysis and interpretation of evidence from the scene of bioterrorism or biocrimes. Mass spectrometry is one of the key techniques in the identification of botulinum neurotoxins, which are among the top six species in the list of bioagents. In this review, I overview the current understanding of structure and function of botulinum neurotoxins, introduce the detection and identification of botulinum neurotoxins, and discuss the progress and the possible strategies of "botulinum neurotoxins signatures" in microbial forensics. The "botulinum neurotoxins signatures" may be obtained using bioanalytical and biophysical methodologies, especially mass spectral proteomics and may provide specific information in detecting and identifying botulinum neurotoxins to combat bioterrorism and biocrimes.
\end{abstract}

Keywords: Clostridium botulinum; Forensic science; Detection; Identification; Microbial forensics

\section{Introduction}

Forensic science is a field using science to solve problems in law $[1,2]$. Forensic scientists apply the principles and techniques of the physical and natural sciences to the analyses of forensic evidences, which are collected in the crime scenes. They also interpret their findings and express their significance in a courtroom as expert witness. Anthrax spore-laden letters were mailed on September 18 and October 9 from Princeton, New Jersey. The letters passed through several states including Florida, New York, and Washington DC. At least 22 individuals were infected and showed symptoms of anthrax by inhalation or cutaneous infection, in which five of the individuals died [3]. Since the 2001 anthrax attacks, members of the biosecurity community and U.S. government officials have expressed a growing sense of alarm at the threats of biological attacks. In particular, the anthrax mailings have disastrous and devastating impact on human health, society, and economy. The threat of terrorist or criminal use of pathogenic organisms and their toxins remains of great concern in the United States and other countries in the world.

A newly emerging discipline, microbial forensics, with an epidemiological foundation is dedicated to the characterization, analysis and interpretation of evidence including bacteria, viruses, and toxins from the scene of acts of bioterrorism or biocrimes [4]. Botulinum neurotoxins (BoNTs) are one of the most important toxins in microbial forensics [5,6]. As one of the top list of biological threats, botulinum neurotoxins (BoNTs) are the most potent natural toxins known to human. As shown in Figure 1, the structural details are able to provide clear insight into the mechanisms how BoNTs interfere with normal release of the neurotransmitter. The three dimensional structures of BoNTs of types A, B, and E have been determined [79] and revealed the three distinct structural and functional domains. The binding domain, which is responsible for cellular receptor-binding function, is located in the C-terminal portion of the heavy chain (HC) [10]. The N-terminal portion of the heavy chain (HN) comprises the translocation domain, which is hypothesized the conformational change at low $\mathrm{pH}$ and promote the escape of light chain from endosome. The light chain containing the catalytic motif is able to cleave different protein factors, which are attached to the protein receptors, and to block the neuromuscular transmission [10].

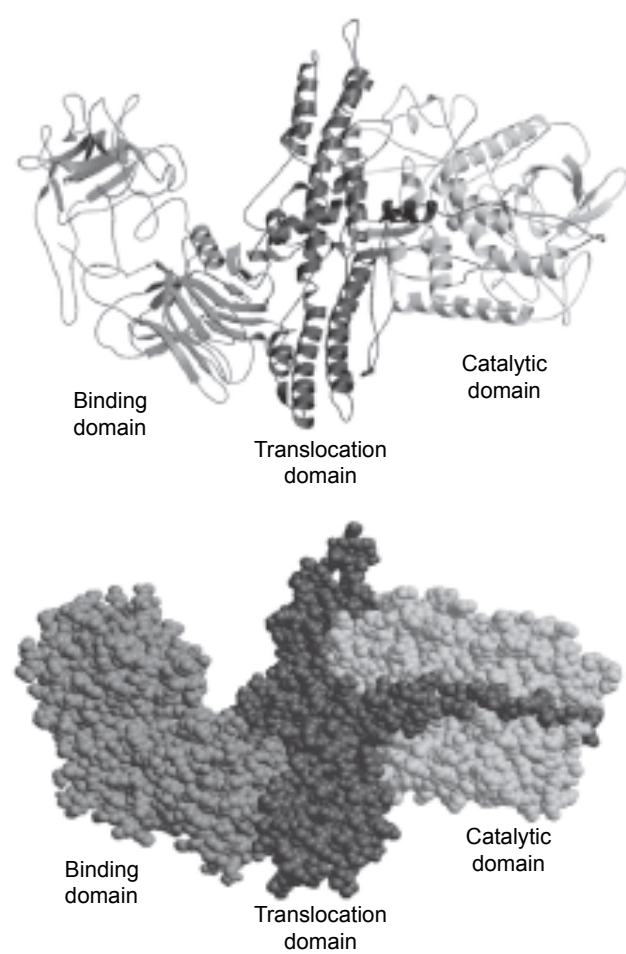

Figure 1: Structure and functional domains of BoNTs (Lacy et al 1998) (reproduced with permission from Nature Publishing Group).

*Corresponding author: Harvey J M Hou, Department of Physical Sciences, Alabama State University, 915 South Jackson Street, Montgomery, Alabama 36104, USA, Tel: 334-229-5121; Fax: 334-229-5049; E-mail: hhou@alasu.edu

Received June 11, 2013; Accepted July 10, 2013; Published July 23, 2013

Citation: Hou HJM (2013) Analysis of Botulinum Neurotoxin Detection by Mass Spectrometry in Forensic Samples. J Forensic Res 4: 185. doi:10.4172/21577145.1000185

Copyright: ( 2013 Hou HJM. This is an open-access article distributed under the terms of the Creative Commons Attribution License, which permits unrestricted use, distribution, and reproduction in any medium, provided the original author and source are credited. 
Mass spectrometry is one of the key techniques in detection and identification of BoNTs [11]. In this review, I briefly summarize the diagnosis of botulism, detection of BoNTs, overview the recent progress in forensic science research, and discuss the potential strategies of "BoNT signatures" in microbial forensics. Using bioanalytical and biophysical methodologies, especially proteomics via mass spectrometry, can assess the "BoNT signatures". The database of "BoNT signatures" will provide insightful information in detection and identification of BoNTs in microbial forensics to combat bioterrorism and biocrimes.

\section{Microbial Forensics}

Typically Forensic analysis is divided into three distinct areas: forensic DNA analysis, trace evidence, and drugs and poisons [12]. Since DNA analysis was first used in forensic investigation in 1985 and is considered the indispensible tool in forensic science to identify the individual involved in a crime investigation [2]. The forensic DNA analysis is one of the most rapid growing areas in forensic science as various technologies and genetic markers have been developed. Short tandem repeat (STR) typing with fluorescence-based detection is now almost universally used in forensic DNA laboratories worldwide. The challenges of badly degraded and damaged DNA samples are addressed by using reduced-sized STR or minSTR. Information on uniparental lineage markers from the Y-chromosome and mitochondrial DNA continues to accumulate in the literature to solve issues associated with evolutionary and genetic genealogy [12].

Physical evidence or trace evidence is low quantities of natural and man-made materials that transfer between objects or between people and objects. Examples of trace evidence are, not limited to, examinations of glass, fiber, paint, debris, gunshot residue (GSR), building material, inks, toners, fingerprint residue and among others [13-17]. A variety of analytical techniques, including use of UVvisible microspectrophotometry [18], Fourier transform infrared spectroscopy (FTIR) with total attenuated reflectance (ATR) [19], Surface-enhanced Raman spectroscopy (SERS) [20], scanning electron microscopy with energy dispersed X-ray spectrometry (SEM-EDS) [21], inductively coupled plasma optical emission spectrometry (ICPOES) [22], atomic absorption spectroscopy (AAS) [23], scanning electrochemical microscopy (SECM) [24], atomic force microscopy (AFM) [25], confocal laser scanning microscopy (CLSM) [26], gas chromatography with mass spectrometry (GCMS)[27] capillary electrophoresis [28] (CE), and laser inducedbreakdown spectroscopy (LIBS) [29], have been used to provide fundamental knowledge and insightful information for forensic cases. Photoacoustic spectroscopy is also used for quantitative and qualitative analysis of explosives, ink, paints, pigments and tissues [30-36].

In forensic science the third area is forensic analysis of drugs and poisons. The major illicit drugs include ethanol and volatiles, cannabionoids, morphine and related narcotics, cocaine, amphetamines, benzodiazepines, $\gamma$ hydroxybuturate (GHB), and miscellaneous drugs. In the past two decades, the analysis of illicit drugs has undergone significant changes. Although the traditional drugs still dominate, more than 100 novel substances have been produced to bypass the controlled substance legislation. These substances cause intoxications and fatalities [37]. The preferred confirmative methodology is gas chromatography-mass spectrometry (GC-MS) and liquid chromatography-mass spectrometry (LC-MS).

Microbial forensic scientists employ comprehensive assays to identify the origin of a pathogen or toxin using a number of techniques.
Microbial forensics is the same as other forensic disciplines except for its focus on a particular type of crime [38]. The purpose of these assays specifically is to track down perpetrators, termed "high tech crime," who employ a biological weapon. The need to conduct microbial forensic analyses to combat bioterrorism and biocrimes is urgent in a rigorous scientific manner. To address this challenge, we must systematically investigate the bacteria, viruses, and fungi as well as their pathogens, toxins, and disease, and the research activities should include the detection, identification, and characterization of these microbial pathogens.

Microbial forensics requires integration and collaboration between the science community and government agencies due to its multifaceted nature. The decision-making is based on pathogen detection and disease diagnosis [39]. The critical steps include the appropriate sample handling techniques, pathogen detection, symptom diagnosis, and assays technologies. Field data including symptoms and epidemiological information are collected to determine the sampling and analysis methodologies. Samples are subject to laboratory assay to detect and identify the presence of microbes or pathogens. Often times, the further confirmative test and diagnosis are required. The field data and test results give a final diagnosis and used for decision making.

A variety of different methodologies used in microbial forensics include the traditional use of host factors, genomics, proteomics, electron beam-based, high throughput sequencing, and non-biological measurements. The main areas in microbial forensics are the collection and preservation of microbial samples, forensic analysis of bacteria pathogens, rickettsia and coxiella diseases, fungal pathogens, plant toxin ricin, influenza virus, and biological toxins botulinum neurotoxins (BoNTs). Future efforts should be continue the development the sensitive, fast, and accurate analytical methodologies for detection and identification of the pathogens including, as well as detailed characterizations of these pathogens under diverse conditions [40].

\section{Overview of BoNTs}

Botulinum neurotoxins are the most poisonous substance in the world, and the fatal amount (LD50) to human is approximately $0.07 \mu \mathrm{g}$ [41]. Botulism is life threatening disease caused by the 150 $\mathrm{kD}$ neurotoxin-producing bacteria including Clostridium botulinum, Clostridium baratii, and Clostridium butyricum (Center for Disease Control and Prevention, 1998) [42]. Type A botulism is most common due to the distribution of C. botulinum spores in the soil [43]. Intoxication can be reached by oral ingestion of toxin or inhalation of aerosolized toxin [44].

In 1899 the first BoNT case was reported, which was caused by a beef tamale [4]. Infant botulism was reported in 1976 [45]. The most common botulism is food borne before 1980 and recent cases are mostly infant or intestinal types [4]. In 1951 wound botulism was described, which was caused by the traumatic wounds [46]. More recent case involved illicit drug uses such heroin [47]. In advertent cases are associated with unintentional exposure in laboratory workers and in patients who receive therapeutic botulinum neurotoxin [4]. The therapeutic uses of toxin were approved by the Food and Drug Administration (FDA) and successfully cure and treat a range of overactive muscle conditions, including cervical dystonias, cerebral palsy, posttraumatic brain injury, and post stroke spasticity $[48,49]$.

BoNTs are stable for days in untreated water and beverages and are an ideal bio-weapon and bio-threat agent [50]. Food-borne botulism is reported with a relatively constant incidence of approximately 25 cases per year between 1899 to 1996 in the United States with a total 
of 1087 cases reported in 1950-1996 [4]. The observations of BoNTs on commercial canned beef stew and potato salad in restaurants have been reported [51,52].

The increasing trend of therapeutic use and the widespread manufacture of BoNTs may provide a potential source of BoNTs. For example, BoNTs has been used unsuccessfully for a intend release by the Japanese cult Aum Shinryko [50]. Both Iraq and the former Soviet Union produced BoNTs for use as a weapon [4]. In Iraq, 10,000 liters of concentrated BoNTs was weaponized in missile and bombs [53]. When an aerosol is release over a metropolitan area, the $1,00,000$ individuals may be exposed to BoNTs. This will result in 50,000 cases with 30,000 fatalities [54]. BoNTs differ significant from each other in their protein sequence. The different responses of antibody allow classification of BoNTs into seven different serotypes: A, B, C, D, E, F, and $G$ [55]. Antibodies that recognize one serotype do not recognize other serotype. Among the seven serotypes, four types of BoNTs are responsible for occurring human botulism, which are serotypes $\mathrm{A}, \mathrm{B}$, $\mathrm{E}$ and $\mathrm{F}[50]$.

It is known that Clostridium botulinum can be divided into four genetically diverse groups: I, II, III, and IV [56]. Additional species, Clostridium butyricum and Clostridium baratii were found to product neurotoxins [57,58], respectively. Genome sequencing, 16S RNA analysis, and amplified fragment length polymorphism provides insights into the evolution of these species [59]. The gene of BoNTs is located in the chromosome or plasmids. Analysis of genomic sequences reveals the presence of insertion element and recombinases that may facilitate the horizontal transfer of BoNTs [60], supporting that toxin may move within species and between species. The gene sequences of BoNTs showed that BoNT/A has five distinct subtypes; BoNT/B has 5 subtypes, and BoNT/E six subtypes [60]. Similarly, BoNT/F has at least five subtypes [61]. In thecases of BoNT/C and BoNT/D, no different subtypes were found [62].

BoNTs functions as a protein complex, which has an apparent molecular mass of approximately $900 \mathrm{kD}$. The complex consists of the neurotoxin and neurotoxin associated proteins (SNPs), which contain hemoglutinins and non-toxin non-hemogglutinins (NTNH). It is proposed that NTNH stabilizes the toxin and avoid the degradation by stress environment [63]. Typical BoNT is an approximately 150 $\mathrm{kD}$ polypeptide, which is composed of a $100 \mathrm{kD}$ heavy chain and a 50 $\mathrm{kD}$ light chain connected by a single disulfide bond. The sequences of genes encoding BoNTs of seven serotypes A-G have been determined $[4,64]$, which indicates that these BoNTs differ by as much as $65 \%$ at amino acid level. However, it is highly likely that they share the same general protein pattern.

The main strategy is antitoxin treatment for therapy, which is most effective at the early phase of botulism [65]. However, when the toxin enters the nerve terminal, antitoxin cannot bind [55]. Antitoxin has limited uses as hypersensitivity may be developed. Workers may protect themselves in lab using investigational pentavalent toxoid. Efforts to generate human monoclonal antibodies for treating botulism are under way [4]. Vaccine using recombinant technology based on the toxin-binding domain is under development [66].

Antibodies is often used for diagnostic tests and therapeutic approaches [4,67]. The most sensitive assay for BoNTs is the mouse bioassay and can detect as little as $33 \mathrm{pg}$ of toxin [68]. In vitro tests to detect BoNTs were developed by mass spectrometry $[69,70]$. These methods for detect toxin from complex matrices such as milk and blood for all seven serotypes [71]. The enzyme-linked immunosorbent assays
(ELISA) for detecting BoNTs were also developed [72,73]. However, current lab tests may not be sensitive for the detection of botulism. It can also take days for cultures or toxin testing results to be available. It is important and critical in the analysis of BoNT detection in forensic samples in terms of limitations of different techniques, sensitivity of assays, detection limits for active neurotoxins, possible cleavage of neurotoxins in forensic samples, and contamination possibilities (false positivity).

\section{BoNT Signatures Analysis}

The ability to trace individual contributing animal or microorganism from a complex mixture is critical in microbial forensics, for example, DNA identification of source animal in food market [74]. Individual muscle fibers were collected from the meat sample and DNA was extracted for profiling. The DNA database is able to identify the specific animal of origin as well as to the track the production parameter and process performance. This provides a practical measure, offers unparalleled ability to detect the contamination, and help characterize the distribution pathway of the affected product.

As forensic science is an applied science of analytical chemistry in law enforcement, the uniqueness of the forensic analysis is to comparison and contrast of the forensic evidence, which may provide a lead in criminal investigation or identifies an individual involved in an incidence. To this end, database is the most powerful technique and has played a key role in forensic investigations. The most successful and widely used databases are automated fingerprint identification system (AFIS), combined DNA indexing system (CODIS), and national integrated ballistics information network (NIBIN) [2]

The chromatographic analysis of cocaine impurity profile provided successfully the potential information of the origin of the illicit drugs [75]. The signature patterns of cocaine samples was recorded as 14 impurities in cocaine samples. The proposed standard procedure is a simple, one step derivatization without pre-preparation (extraction or chemical modification) to obtain such a chromatographic signature profile. The experimental data indicated that the presented procedure was sufficiently sensitive for determine the origin ("sample batch") of cocaine samples. With the reliable computerized pattern recognition, program and more sensitive methodology itis likely the cocaine impurity signature profile would able to determine the country of origin of unknown cocaine sample. Similar methodologies to obtain the signature patterns for amphetamine [76], methamphetamine [77], opium alkaloids [78], and cannabis [79] were explored and established.

To the best of our knowledge, there is no report on BoNT signature analysis in forensic science. Mass spectrometry is a powerful tool in identification of BoNTs and application in proteomics. Figure 2 showed a diagram of mass spectral proteomics analysis [80]. A complex protein mixture is analyzed directly (top-down proteomics) or digested into peptides (bottom-up proteomics). The proteins or peptides samples are separated using liquid chromatography and subsequently analyzed using tandem mass spectrometry to obtain the molecular weights and protein sequence information via parent and tandem mass spectra. The "bottom-up" proteomics uses the small peptide or protein fragment and has better specificity and sensitivity than the "topdown"method. However, the potential information on protein modifications such as oxidation or phosphorylation may be lost by this method alone. The BoNT signature profile can be determined by the combination of "topdown" and "bottom-up" proteomics. The database of "BoNT signature" may be generated and used for the detection and identification of BoNTs in forensic science. 


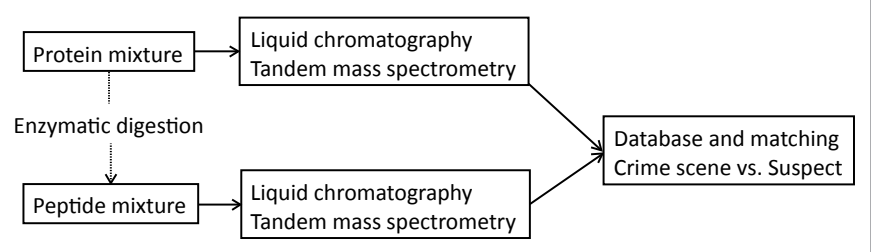

Figure 2: Mass spectral proteomics analysis of botulinum neurotoxins.

In addition to the mass spectrometry, two other outstanding analytical techniques might be used in the signature analysis of BoNT would be chromatography and FTIR. Chromatographic analysis including the capillary gas chromatography and high performance liquid chromatography is successfully used in forensic drug impurity signature analysis such as methamphetamine [81,82], marijuana [79], heroin [78], and cocaine [75]. As the BoNT is a protein sample, the capillary gas chromatography is ideal for organic compounds with a molecular mass limit of 500 and would not appropriate for BoNT analysis. High performance liquid chromatography is reasonable and sensitive for the signature analysis of BoNT; however, it requires a longer time for conducting on measurement than mass spectrometry. FTIR is fruitfully utilized for tap and fiber analysis [16,17]. Due to the fact that protein samples such as BoNT has significant overlap of IR signals in amide structure, FTIR might be limited and problematic in signature analysis of BoNT. In addition, the sensitivity of FTIR is lower than mass spectroscopy.

\section{Conclusions}

The key element in forensic analysis is to match an unknown from crime scene and a known from a suspect and to provide scientific sounding evidence for the lead to solve the legal issue in crime investigation. To this end, the databases, including fingerprint, DNA profiling, and firearm information, are particularly powerful tool. As an emerging field and a national need, microbial forensics has been a significantly expended field in terms of detection and identification of the source of microorganisms in the past ten years [4]. The detailed characterization of the bacteria, viruses and toxins are especially worthwhile to provide a complete categories and classification of the microorganisms in forensic sciences. As documented in this review, BoNTs are one of the top biological weapons in bioterrorism and biocrimes, may be assessed using the signature analysis and potential building a "BoNT signature" database using mass spectral proteomics. This approach may provide specific and detailed information in detection and identification of BoNTs in microbial forensics and potentially serves a model system to inspire the forensic analysis of other bacteria or viruses to combat bioterrorism and biocrimes.

\section{Acknowledgements}

The work was supported by the Alabama State University. I thank Brian Chait at Rockefeller University and Bal Ram Singh at UMass Dartmouth for their collaboration and support.

\section{References}

1. Gaensslen R, Harris H, Lee H (2008) Introduction to Forensic Science and Criminalistics. McGraw-Hill.

2. Saferstein R (2011) Criminalistics, (10th ed.), Prentice Hall.

3. Jernigan JA, Stephens DS, Ashford DA, Omenaca C, Topiel MS, et al. (2001) Bioterrorism-related inhalational anthrax: the first 10 cases reported in the United States. Emerg Infect Dis 7: 933-944.

4. Budowle B, Schultzer S, Breeze R, Keim P, SA M (2010) Microbial Forensics. Academic Press.
5. Marks JD (2010) Forensic aspects of biological toxins. In: Budowle B, Schutze SE, Breeze RG, Keim PS, and Morse SA (Eds). Microbial Forensics, (2nd edn)., Academic Press: 327-353.

6. Okinaka RT, Hill KH, Person T, Foster JT, Vogler A, et al.(2010) Forensic analysis in bacterial pathogens. In: Microbial Forensics, BruceBudowle, Steven E. Schutzer, Roger G. Breeze, Paul S. Keim, Stephen A. Morse(Eds) Academic Press: 259-276.

7. Lacy DB, Tepp W, Cohen AC, DasGupta BR, Stevens RC (1998) Crystal structure of botulinum neurotoxin type $A$ and implications for toxicity. Nat Struct Biol 5: 898-902.

8. Kumaran D, Eswaramoorthy S, Furey W, Navaza J, Sax M, et al. (2009) Domain organization in Clostridium botulinum neurotoxin type $E$ is unique: its implication in faster translocation. J Mol Biol 386: 233-245.

9. Dolly JO, Black J, Williams RS, Melling J (1984) Acceptors for botulinum neurotoxin reside on motor nerve terminals and mediate its internalization. Nature 307: 457-460.

10. Schiavo G, Benfenati F, Poulain B, Rossetto O, Polverino de Laureto $P$, et al (1992) Tetanus and botulinum-B neurotoxins block neurotransmitter release by proteolytic cleavage of synaptobrevin. Nature 359: 832-835.

11. Johnson RC, Kalb SR, Barr JR (2010) Toxin analysis using mass spectrometry In: Microbial Forensics, Bruce Budowle, Steven E. Schutzer, Roger G. Breeze, Paul S, Keim, Stephen A. Morse (Eds): 405-420.

12. Brettell TA, Butler JM, Almirall JR (2011) Forensic science. Anal Chem 83 4539-4556.

13. Burks RM, Hage DS (2009) Current trends in the detection of peroxide-based explosives. Anal Bioanal Chem 395: 301-313.

14. Germain ME, Knapp MJ (2009) Optical explosives detection: from color changes to fluorescence turn-on. Chem Soc Rev 38: 2543-2555.

15. Goodpaster JV, Sturdevant AB, Andrews KL, Briley EM, Brun-Conti L (2009) Identification and comparison of electrical tapes using instrumental and statistical techniques: II. Organic composition of the tape backing and adhesive. J Forensic Sci 54: 328-338.

16. Goodpaster JV, Liszewski EA (2009) Forensic analysis of dyed textile fibers Anal Bioanal Chem 394: 2009-2018.

17. Dalby O, Butler D, Birkett JW (2010) Analysis of gunshot residue and associated materials--a review. J Forensic Sci 55: 924-943.

18. Barrett JA, Siegel JA, Goodpaster JV (2010) Forensic discrimination of dyed hair color: I. UV-visible microspectrophotometry. J Forensic Sci 55: 323-333.

19. Szafarska M, Wozniakiewicz M, Pilch M, Zieba-Palus J, Koscielniak P (2009) Computer analysis of ATR-FTIR spectra of paint samples for forensic purposes. J Mol Struct 924-926: 504-513.

20. Connatser RM, Prokes SM, Glembocki OJ, Schuler RL, Gardner CW, et al (2010) Toward surface-enhanced Raman imaging of latent fingerprints. J Forensic Sci 55: 1462-1470.

21. Pessanha S, Manso M, Guilherme A, Costa M, Carvalho M (2010) Investigation of historical documents for forensci purposes by $x$-ray fluorescence spectrometry. Surf Interface Anal 42: 419-422.

22. Chojnacka K, Zieliß̊,,ska A, Michalak I, GÃ $\tilde{A}^{3}$ ecki H (2010) The effect of dietary habits on mineral composition of human scalp hair. Environ Toxicol Pharmacol 30: 188-194.

23. Baysal A, Akman S (2010) Determination of lead in hair and its segmental analysis by solid sampling electrothermal atomic absorption spectrometry. Spectrochim Acta B 65: 340-344.

24. Zhang M, Girault HH (2009) SECM for imaging and detection of latent fingerprints. Analyst 134: 25-30.

25. Canetta E, Montiel K, Adya AK (2009) Morphological changes in textile fibres exposed to environmental stresses: atomic force microscopic examination. Forensic Sci Int 191: 6-14.

26. Kirkbride KP, Tridico SR (2010) The application of laser scanning confocal microscopy to the examination of hairs and textile fibers: an initial investigation. Forensic Sci Int 195: 28-35

27. Cook GW, LaPuma PT, Hook GL, Eckenrode BA (2010) Using gas chromatography with ion mobility spectrometry to resolve explosive compounds in the presence of interferents. J Forensic Sci 55: 1582-1591. 
Citation: Hou HJM (2013) Analysis of Botulinum Neurotoxin Detection by Mass Spectrometry in Forensic Samples. J Forensic Res 4: 185. doi:10.4172/2157-7145.1000185

Page 5 of 6

28. Sarazin C, Delaunay N, Varenne A, Vial J, Costanza C, et al. (2010) Identification and determination of inorganic anions in real extracts from pre- and post-blast residues by capillary electrophoresis. J Chromatogr A 1217: 6971-6978.

29. Dockery CR (2005) Laser-induced breakdown spectroscopy: Sampling techniques for forensic and environmental applications. University of South Carolina.

30. Rockley MG, Woodard M, Richardson HH, Davis DM, Purdie N, et al. (1983) Determination of phencyclidine and phenobarbital in complex mixtures by Fourier-transformed infrared photoacoustic spectroscopy. Anal Chem 55: $32-$ 34.

31. Bernini U, Marotta M, Martino G, Russo P (1991) Spectrophotoacoustic method for quantitative estimation of haem protein content in wet tissue. Phys Med Biol 36: 391-396

32. Wahls MWC, Leyte JC (1998) Fourier transform infrared photoacoustic spectroscopy of polymeric laminates. J Appl Phys 83: 504-509.

33. Jimenez-Perez JL, Jimenez-Perez J, Cruz BA, cruz-Orea A, Mendoza-Alvarez JG (2004) Photoacoustic Analysis of Pigments from Archeological Ceramics. Int $\mathrm{J}$ Thermophys 25: 503-510.

34. Cappitelli F, Vicini S, Piaggio P, Abbruscato P, Princi E, et al. (2005) Investigation of fungal deterioration of synthetic paint binders using vibrational spectroscopic techniques. Macromol Biosci 5: 49-57.

35. Kinnunen M, Myllyla R (2005) Effect of glucose on photoacoustic signals at the wavelengths of $1064 \mathrm{~nm}$ and $532 \mathrm{~nm}$ in pig blood and intralipid. J Phys D 38: 2654.

36. von Aderkas EL, Barsan MM, Gilson DF, Butler IS (2010) Application of photoacoustic infrared spectroscopy in the forensic analysis of artists' inorganic pigments. Spectrochim Acta A Mol Biomol Spectrosc 77: 954-959.

37. Wohlfarth A, Weinmann W (2010) Bioanalysis of new designer drugs Bioanalysis 2: 965-979.

38. Budowle B, Schutzer SE, Einseln A, Kelley LC, Walsh AC, et al. (2003) Public health. Building microbial forensics as a response to bioterrorism. Science 301 : 1852-1853.

39. Fletcher J, Barnaby N, Burans J, Melcher U, Nutter Jr. F, et al. (2010) Forensic plant pathology. In: Budowle B, Schutzer SE, Breeze RG, Keim PS, and Morse SA (Eds). Microbial Forensics.(2nd Edn), Academic Press: 89-105.

40. Hou HJM, Scissum-Gunn K, Wu H, Akujuobi C (2012) Microbial forensics: An emerging field and a national need. Air Water Borne Diseases 1: e107.

41. Gill DM (1982) Bacterial toxins: a table of lethal amounts. Microbiol Rev 46: 86-94

42. Center for Disease Control and Prevention (1998) Botulism in the united states 1899-1998. Handbook for epdemiologists, clinicians, and laboratory workers, Atlanta,Georgia.

43. Smith LD (1978) The occurrence of Clostridium botulinum and Clostridium tetani in the soil of the United States. Health Lab Sci 15: 74-80.

44. Park JB, Simpson LL (2003) Inhalational poisoning by botulinum toxin and inhalation vaccination with its heavy-chain component. Infect Immun 71: 11471154.

45. Pickett J, Berg B, Chaplin E, Brunstetter-Shafer MA (1976) Syndrome of botulism in infancy: clinical and electrophysiologic study. N Engl J Med 295: 770-772.

46. DAVIS JB, MATTMAN LH, WILEY M (1951) Clostridium botulinum in a fatal wound infection. J Am Med Assoc 146: 646-648.

47. Werner SB, Passaro D, McGee J, Schechter R, Vugia DJ (2000) Wound botulism in California, 1951-1998: recent epidemic in heroin injectors. Clin Infect Dis 31: 1018-1024.

48. Mahant N, Clouston PD, Lorentz IT (2000) The current use of botulinum toxin $\mathrm{J}$ Clin Neurosci 7: 389-394.

49. Kennedy D (2002) Beauty and the beast. Science 295: 1601.

50. Arnon SS, Schechter R, Inglesby TV, Henderson DA, Bartlett JG, et al. (2001) Botulinum toxin as a biological weapon: medical and public health management. JAMA 285: 1059-1070.

51. Blake PA, Horwitz MA, Hopkins L, Lombard GL, McCroan JE, et al. (1977) Type A botulism from commercially canned beef stew. South Med J 70: 5-7.

52. Seals JE, Snyder JD, Edell TA, Hatheway CL, Johnson CJ, et al. (1981)
Restaurant-associated type A botulism: transmission by potato salad. Am J Epidemiol 113: 436-444

53. Zilinskas RA (1997) Iraq's biological weapons. The past as future? JAMA 278 418-424.

54. St John R, Finlay B, Blair C (2001) Bioterrorism in Canada: An economic assessment of prevention and postattack response. Can J Infect Dis 12: 275 284

55. Sugiyama H (1980) Clostridium botulinum neurotoxin. Microbiol Rev 44: 419448.

56. Hatheway CL (1990) Toxigenic clostridia. Clin Microbiol Rev 3: 66-98.

57. Hall JD, McCroskey LM, Pincomb BJ, Hatheway CL (1985) Isolation of an organism resembling Clostridium barati which produces type $\mathrm{F}$ botulinal toxin from an infant with botulism. J Clin Microbiol 21: 654-655.

58. Aureli P, Fenicia L, Pasolini B, Gianfranceschi M, McCroskey LM, et al. (1986) Two cases of type $E$ infant botulism caused by neurotoxigenic Clostridium butyricum in Italy. J Infect Dis 154: 207-211.

59. Hill KK, Smith TJ, Helma CH, Ticknor LO, Foley BT, et al. (2007) Genetic diversity among Botulinum Neurotoxin-producing clostridial strains. J Bacterio 189: 818-832.

60. Hill KK, Xie G, Foley BT, Smith TJ, Munk AC, et al. (2009) Recombination and insertion events involving the botulinum neurotoxin complex genes in Clostridium botulinum types $\mathrm{A}, \mathrm{B}, \mathrm{E}$ and $\mathrm{F}$ and Clostridium butyricum type $\mathrm{E}$ strains. BMC Biol 7: 66

61. Smith TJ, Lou J, Geren IN, Forsyth CM, Tsai R, et al. (2005) Sequence variation within botulinum neurotoxin serotypes impacts antibody binding and neutralization. Infect Immun 73: 5450-5457.

62. Curran RM, Fringuelli E, Graham D, Elliott CT (2009) Production of serotype $C$ specific and serotype $C / D$ generic monoclonal antibodies using recombinan $\mathrm{H}(\mathrm{C})$ and $\mathrm{H}(\mathrm{N})$ fragments from Clostridium botulinum neurotoxin types $\mathrm{C}(1)$ and D. Vet Immunol Immunopathol 130: 1-10.

63. Chen F, Kuziemko GM, Stevens RC (1998) Biophysical characterization of the stability of the 150-kilodalton botulinum toxin, the nontoxic component, and the 900-kilodalton botulinum toxin complex species. Infect Immun 66: 2420-2425.

64. Ihara H, Kohda T, Morimoto F, Tsukamoto K, Karasawa T, et al. (2003) Sequence of the gene for Clostridium botulinum type B neurotoxin associated with infant botulism, expression of the C-terminal half of heavy chain and its binding activity. Biochim Biophys Acta 1625: 19-26.

65. Tacket CO, Shandera WX, Mann JM, Hargrett NT, Blake PA (1984) Equine antitoxin use and other factors that predict outcome in type A foodborne botulism. Am J Med 76: 794-798.

66. Byrne MP, Smith LA (2000) Development of vaccines for prevention of botulism Biochimie 82: 955-966.

67. Singh BR (2006) Botulinum neurotoxin structure, engineering, and nove cellular trafficking and targeting. Neurotox Res 9: 73-92.

68. Schantz EJ, Johnson EA (1992) Properties and use of botulinum toxin and other microbial neurotoxins in medicine. Microbiol Rev 56: 80-99.

69. Barr JR, Moura H, Boyer AE, Woolfitt AR, Kalb SR, et al. (2005) Botulinum neurotoxin detection and differentiation by mass spectrometry. Emerg Infect Dis 11: 1578-1583.

70. Boyer AE, Moura H, Woolfitt AR, Kalb SR, McWilliams LG, et al. (2005) From the mouse to the mass spectrometer: detection and differentiation of the endoproteinase activities of botulinum neurotoxins A-G by mass spectrometry. Anal Chem 77: 3916-3924.

71. Kalb SR, Moura H, Boyer AE, McWilliams LG, Pirkle JL, et al. (2006) The use of Endopep-MS for the detection of botulinum toxins $A, B, E$, and $F$ in serum and stool samples. Anal Biochem 351: 84-92.

72. Cai S, Singh BR, Sharma S (2007) Botulism diagnostics: from clinical symptoms to in vitro assays. Crit Rev Microbiol 33: 109-125.

73. Grate J, Warner M, Ozanich RM Jr. Miller K, Colburn H, et al. (2009) Renewable surface fluorescence sandwich immunoassay biosesor for rapic sensitive botulinum toxin detection in an automated fluidic format. Analyst 134: 987-996.

74. Loftus R, Meghen C (2010) Tracing meat products through the production and distribution chain from farm to consumer. In: Budowle B, Schutzer SE, Breeze 
Citation: Hou HJM (2013) Analysis of Botulinum Neurotoxin Detection by Mass Spectrometry in Forensic Samples. J Forensic Res 4: 185. doi:10.4172/2157-7145.1000185

RG, Keim PS, and Morse SA (Eds). Microbial Forensics (2nd Edn), Academic Press: $59-73$.

75. Casale J, Waggoner RJ (1991) A chromatographic impurity sygnature profile analysis for cocaine using capillary gas chromatography. J Forensic Sci 36: $1312-1330$.

76. Sanger DG, Humphreys IJ, Patel AC, Japp M, Osborne RGL (1985) The significance of gas chromatographic impurity patterns obtained from illicitly produced amphetamine. Forensic Sci Int 28: 7-17.

77. Allen A, Cantrell T (1989) Synthetic reductions in clandestine amphetamine and methamphetamine laboratories: A review. Forensic Sci Int 42: 183-199.

78. Moore JM, Allen AC, Cooper DA (1986) Determination of neutral manufacturing impurities in heroin by capillary gas chromatography with electron capture detection after reduction with lithium aluminum hydride and derivatization with heptafluorobutyric anhydride. Anal Chem 58: 1003-1007.

79. Brenneisen R, elSohly MA (1988) Chromatographic and spectroscopic profiles of Cannabis of different origins: Part I. J Forensic Sci 33: 1385-1404.

80. Wahl K, Wunschel D, Clowers B (2010) Proteomics development and application for bioforensics. In: Budowle B, Schutzer SE, Breeze RG, Keim PS, and Morse SA (Eds). Microbial Forensics (2nd Edn)., Academic Press 449-460.

81. Kram TC (1979) Reidentification of a major impurity in illicit amphetamine. J Forensic Sci 24: 596-599.

82. Allen AC, Kiser WO (1987) Methamphetamine from Ephedrine: I. Chloroephedrines and Aziridines. J Forensic Sci 32: 953-962 .

This article was originally published in a special issue, Forensic Microbiology \& Forensic Pathology handled by Editor(s). Dr. Hiroshi Ikegaya, Kyoto Prefectural University of Medicine, Japan 